\title{
ANALISIS MUATAN NILAI-NILAI KARAKTER PADA BUKU PEGANGAN SISWA IPA SMP KELAS VII SEMESTER 2 KURIKULUM 2013
}

\author{
Rohmatus Syafi'ah \\ STKIP PGRI Tulungagung \\ rohmatus.syafi@yahoo.com
}

\begin{abstract}
ABSTRAK
Penelitian ini bertujuan untuk mendeskripsikan nilai-nilai karakter pada buku pegangan Siswa IPA SMP kelas VII semester 2 kurikulum 2013 dan kesesuaian nilai-nilai karakter dengan nilai-nilai karakter yang tercantum dalam Permendikbud No. 21 tahun 2016. Penelitian ini menggunakan pendekatan deskriptif kualitatif. Subjek utama yang digunakan berupa buku pegangan siswa berjudul Ilmu Pengetahuan Alam SMP/ MTs Kelas VII Semester 2 cetakan ke-3 tahun 2016 (edisi revisi). Unit analisis adalah nilai-nilai karakter yang terkandung dalam buku pegangan siswa. Pengumpulan data dalam penelitian ini dilakukan dengan analisis isi dan pencatatan secara cermat terhadap buku pegangan siswa tersebut. Hasil penelitian menunjukkan bahwa buku pegangan siswa IPA SMP Kelas VII semester 2 berbasis kurikulum 2013 memuat nilai pendidikan karakter yang sesuai dengan uraian nilai-nilai karakter yang tercantum dalam Permendikbud No. 21 tahun 2016 tentang Standar Isi Kurikulum 2013 untuk sekolah dasar dan menengah yaitu religius, jujur, disiplin, santun, percaya diri, peduli, dan tanggung jawab. Selain ke tujuh nilai karakter yang tercantum dalam Permendikbud No. 21 tahun 2016 tersebut di dalam buku pegangan siswa juga ditemukan 8 nilai karakter lain yaitu kreatif, rasa ingin tahu, menghargai kerja individu/kerja kelompok/pendapat orang lain, komunikatif, teliti, mandiri, gemar membaca dan kerjasama.
\end{abstract}

Kata kunci: buku pegangan siswa, kurikulum 2013, nilai-nilai karakter.

\section{ABSTRACT}

This research aims to describe the character value in student handbook IPA SMP Kelas VII Semester 2 in kurikulum 2013 and the suitability of the character valuewith the character values was published byPermendikbud No. 21 of 2016. This research using thequalitative descriptive approach. The main subject used in this research was student handbook entitled Ilmu Pengetahuan Alam SMP/ MTs Kelas VII Semester 2of the 3rd printed year 2016 (revised edition). The unitanalysis of this research is the character contained in the student handbook. Data collection in this research was carried out by analyzing content and carefully recording the student handbook. The results of the researchshow that student handbook IPA for 7th Grade Junior High School contains character education values in accordance with the indicators of character education essay that was published byPermendikbud No. 21 of 2016 concerning Standard Content for 2013 Curriculum for primary and secondary schools.Those values are religious, honesty, discipline, polite, confident, care, and responsibility. In addition to the seven character values listed in Permendikbud No. 21 of 2016 in the student handbook also found 8 other character value. Those values are creativity, curiosity, appreciateto individual work / group work / other people's opinions, communication, thorough, independence, passion to read and cooperation. 
Keywords: student handbook, 2013 curriculum, character values.

\section{PENDAHULUAN}

Pembangunan karakter yang merupakan upaya perwujudan amanat Pancasila dan Pembukaan UUD 1945 dilatarbelakangi oleh realita permasalahan yang terjadi saat ini akibat adanya efek globalisasi yang mengakibatkan terjadinya berbagai persoalan di dunia, seperti merosotnya nilai-nilai budaya dan moral kebangsaan, yang berpengaruh terhadap lunturnya identitas kebangsaan. Selain itu, penyebaran informasi yang begitu cepat melalui media internet, handphone, televisi, atau media-media lain dapat diakses oleh semua kalangan termasuk peserta didik. Informasi-informasi yang sering terdengar saat ini berupa perkelahian, bullying tawuran antarpeserta didik, pacaranbebas, pemerkosaan, pembunuhan guru oleh peserta didik, pembunuhan orang tua oleh anak, dan lain sebagainya. Mirisnya, kejadian-kejadian tersebut justru paling banyak terjadi di kalangananak usia sekolah. Salah faktor yang menjadi penyebabnya adalah kurangnya pengembangan nilai-nilai karakter dalam diri peserta didik. Oleh karena itu, untuk mengatasi permasalahanpermasalahan tersebut pemerintah menjadikan pembangunan karakter sebagai salah satu prioritas pembangunan nasional.

Visi pembangunan nasional yaitu mewujudkan masyarakat berakhlak mulia, bermoral, beretika, berbudaya, dan beradab berdasarkan falsafah Pancasila berlandaskan pada pendidikan karakter. Pendidikan karakter bukan sekedar mengajarkan mana yang benar dan mana yang salah tetapi juga menanamkan kebiasaan baik sehingga peserta didik menjadi paham (kognitif) tentang mana yang benar dan yang salah, merasakan (afektif) nilai yang baik dan biasa melakukannya (psikomotor) (Daryanto dan dwicahyono, 2014).Penerapan pendidikan karakter harus membudaya dan benarbenar dilakukan di sekolahdan bukan hanya menjadi program tertulis
saja(Lewis, Robinson, \& Hayes, 2013).Pengembangan pendidikan karakter di lingkungan pendidikan atau sekolah saat ini salah satunya terintegrasi melalui Kurikulum 2013.

Empat kompetensi inti yang terkandung dalam kurikulum 2013 berdasarkan Peraturan Menteri Pendidikan dan KebudayaanNomor 20 Tahun 2016yaitu kompetensi sikap spiritual,sikap sosial, pengetahuan, dan keterampilan. Peraturan Menteri Pendidikan dan Kebudayaan No. 21 (2016) Tentang Standar Isi Pendidikan Dasar dan Menengah menjelaskan bahwa karakter yang harus tertanam pada diri siswa terdapat dalamkompetensi sikap spiritual dan kompetensi sikap sosial. Nilai-nilai karakter tersebut yaitu religius, jujur, disiplin, santun, percaya diri, peduli, dan bertanggung jawab. Salah satu cara penanaman nilai-nilai karakter yang dapat dilakukan di sekolah adalah melalui bahan ajar yang diajarkan melalui kegiatan pembelajaran.

Bahan ajar yang digunakan dalam Kurikulum2013 adalah bahan ajar cetak yaitu buku ajar yang biasa disebut buku pegangan siswa.Camblis dan Calfee (dalam Ridwan dan Mudiono, 2017) menjelaskan bahwa buku ajar memiliki kekuatan yang luar biasa besar terhadap perubahan otak siswa dan buku ajar dapat memengaruhi pengetahuan anak dan nilai nilai tertentu. Sesuai dengan pendapat tersebut dalam kegiatan pembelajaran buku ajar dapat digunakan sebagai sumber belajar siswa tentang pengetahuan dan nilai-nilai karakter yang bermanfaat untuk masa depannya.

Nilai-nilai karakter yang harus ditanamkan pada peserta didikuntuk siswa Sekolah Menengah Pertama (SMP)dalam kurikulum 2013pada mata pelajaran IPA salah satunya terkandung dalam buku pegangan wajib siswa yang berjudul Ilmu Pengetahuan Alam SMP/ MTs Kelas VII Semester 1 dan 2 cetakan ke-3 tahun 2016 
(edisi revisi).Buku teks atau buku pegangan siswa merupakan buku yang layak dan menjadi buku utama yang digunakan dalam pembelajaran Kurikulum 2013 (Permendikbud Nomor 8 Tahun 2016). Penggunaan buku pegangan siswa yang merata di seluruh lembaga formal memiliki pengaruh besar dan dampak yang luas sebagai referensi. Lickona (2008) menjelaskan bahwateks atau buku pegangan siswa yang memiliki fungsi sebagai referensi merupakan sumber daya yang paling berhargapada kelas etika.

Hasil penelitian Siwi, dkk (2016) membuktikan bahwanilai pendidikan karakter meliputi nilai religius, jujur, toleransi, disiplin, kerja keras, kreatif, mandiri, demokratis, rasa ingin tahu, semangat kebangsaan, cinta tanah air, menghargai prestasi, komunikatif, gemar membaca, peduli lingkungan dan tanggung jawab ditemukan dalam buku teks pelajaran IPA kurikulum 2013 pada materi Biologi kelas VII SMP. Berdasarkan hasil penelitian di atasdan adanya tuntutan penanaman pendidikan karakter pada peserta didik, menjadi alasandilakukannya penelitian dengan judul "Analisis Muatan Nilai-Nilai Karakter Pada Buku Pegangan Siswa IPA SMP Kelas VII Semester 2 Kurikulum 2013" sebagai langkah sederhana untuk menguraikannilainilaikarakter yang terkandung dalam buku pegangan siswa Kurikulum 2013 pelajaran IPA kelas VII semester 2.

\section{METODE}

Penelitian ini merupakan penelitian deskriptif kualitatif. Subjek utama yang digunakan berupa buku pegangan siswa berjudul "Ilmu Pengetahuan Alam SMP/ MTs Kelas VII Semester 2 cetakan ke-3 tahun 2016 (edisi revisi)"yang ditulis oleh Widodo, dkk (2016) dan diterbitkan oleh Kemdikbud. Nilai karakter yang terdapat pada buku pegangan siswa mata pelajaran IPA kelas VII semester 2 Kurikulum 2013 merupakan bagian yangdianalisis dalam penelitian ini. Metode pengambilan sampel menyadur dari Chabalengula et al. (1993) dengan bagian yang dianalisis meliputi paragraf lengkap, pertanyaan-pertanyaan, gambar-gambar, tabel beserta keterangannya, dan uraian kegiatan laboratorium. Analisis isi dan pencatatan secara cermat terhadap buku pegangan siswa meruapakan langkah yang diambil dalam pengumpulan data, sedangkan instrumen utama dalam penelitianini adalah human instrument, yaitu penelitisendiri.

Keabsahan data didasarkan pada validitassemantik yang digunakan untuk mengetahuikecocokan antara analisis kategori teks dankonteks yang dipilih. Reliabilitas stabilitasdan reliabilitas replikabilitas merupakan reliabilitas instrumen yang digunakan dalam penelitian ini. Reliabilitas stabilitas dilakukan dengan cara membaca berulang untuk mendapatkan pemahaman yang mendalam, sementara konfirmasi dengan teman sejawat dan diskusi merupakan langkah yang diambil dalam reliabilitas replikabilitas. Prosedur analisis konten mengacu pada Krippendorf, 2013 yang terdiri atas empat langkah, yaitu pengadaandata (terdiri atas 3 bagian yaitu penentuan unit analisis, penentuan sampel, dan pencatatan), reduksi data (menghilangkan segala sesuatu yang tidak sesuai dengan nilai-nilai karakter), inferensi (menggunakan kriteria penentuan nilai karakter yang terdapat dalam teks), dananalisis data. Teknik analisis data menggunakan teknik analisis deskriptif kualitatif.

\section{HASIL}

Buku pegangan siswa mata pelajaran IPA kurikulum 2013 kelas VII semester 2 terdiri atas 6 bab yaitu sistem organisasi kehidupan, interaksi makhluk hidup dengan lingkungan, pencemaran lingkungan, pemanasan global, lapisan bumi, dan tata surya. Temuan nilai karakter pada buku pegangan siswa mata pelajaran IPA kelas VII semester 2 kurikulum 2013 disajikan pada Tabel 1 berikut ini. 
Tabel 1 Jumlah Temuan Nilai-nilai Karakter dalam Buku Pegangan Siswa Mata Pelajaran IPA Kelas VII semester 2 Kurikulum 2013.

\begin{tabular}{|c|c|c|c|c|c|c|c|}
\hline \multirow[b]{2}{*}{ No. } & \multirow[b]{2}{*}{ Nilai Karakter } & \multicolumn{6}{|c|}{ Jumlah Temuan pada Bab: } \\
\hline & & $\begin{array}{c}\text { Sistem } \\
\text { Organisasi } \\
\text { Kehidupan }\end{array}$ & $\begin{array}{c}\text { Interaksi } \\
\text { Makhluk } \\
\text { Hidup dengan } \\
\text { Lingkungan }\end{array}$ & $\begin{array}{l}\text { Pencemaran } \\
\text { Lingkungan }\end{array}$ & $\begin{array}{c}\text { Pemanasan } \\
\text { Global }\end{array}$ & $\begin{array}{l}\text { Lapisan } \\
\text { Bumi }\end{array}$ & $\begin{array}{l}\text { Tata } \\
\text { Surya }\end{array}$ \\
\hline 1. & Religius & 2 & - & - & 1 & - & 1 \\
\hline 2. & Jujur & 7 & 4 & 2 & 2 & - & 3 \\
\hline 3. & Disiplin & 1 & 3 & - & 2 & - & - \\
\hline 4. & Santun & 5 & 4 & 2 & 3 & 3 & 4 \\
\hline 5. & Percaya Diri & 2 & 4 & 1 & 3 & 3 & 4 \\
\hline 6. & Peduli & 4 & 3 & - & 2 & 1 & - \\
\hline 7. & Tanggung Jawab & 9 & 5 & 2 & 3 & 6 & 4 \\
\hline 8. & Kreatif & 4 & 2 & - & 1 & 8 & 1 \\
\hline 9. & Rasa Ingin Tahu & 12 & 10 & 5 & 2 & 12 & 3 \\
\hline 10 & $\begin{array}{l}\text { Menghargai kerja } \\
\text { Individu/kerja } \\
\text { kelompok/pendap } \\
\text { at orang lain }\end{array}$ & 9 & 5 & 2 & 3 & 4 & 4 \\
\hline 11. & Komunikatif & 5 & 5 & 2 & 3 & 4 & 4 \\
\hline 12. & Gemar Membaca & 2 & - & - & - & 4 & - \\
\hline 13. & Teliti & 13 & 7 & 2 & 2 & 5 & 3 \\
\hline 14. & Mandiri & 12 & 5 & 1 & 1 & 9 & 1 \\
\hline 15. & Kerjasama & 1 & 2 & 1 & 3 & 4 & 4 \\
\hline
\end{tabular}

Data pada Tabel 1 menunjukkan adanya kesesuain antara nilai karakter yang ditemukan pada buku pegangan siswa IPA kelas VII semester 2 dengan nilai karakter yang tercantum dalam Permendikbud No. 21 tahun 2016 tentang Standar Isi Kurikulum2013 untuk sekolah dasar dan menengahyaitu religius, jujur, disiplin, santun, percaya diri, peduli, dan tanggung jawab. Selain ke tujuh nilai karakter yang tercantum dalam Permendikbud No. 21 tahun 2016 tersebut di dalam buku pegangan siswa juga ditemukan 8 nilai karakter lain yaitu kreatif, rasa ingin tahu, menghargai kerja individu/kerja kelompok/pendapat orang lain, komunikatif, teliti, mandiri, dan kerjasama.

\section{PEMBAHASAN}

Buku pegangan siswa dapatdigunakan sebagai salah satu media untuk mengembangkannilai-nilai karakter dalam pembelajarankarena peserta didik lebih sering berinterksi langsung dengan buku pegangan siswa dibandingkan denganguru kelasnya.Peran penting buku pegangan siswa dalam proses pembelajaran selain untuk memudahkan peserta didik mempelajari materi yang diberikan, yaitu sebagai salah satu media dalam menanamkan dan mengembangkan pendidikan karakter pada peserta didik. Karakter merupakan ciri khas pribadi kita yang membedakan dengan orang lain (Bohlin, 2005).

Nilai-nilai karakter yang terkandung dalam buku pegangan siswa IPA kelas VII semester 2 kurikulum 2013sudah sesuai dengan Permendikbud No. 21 Tahun 2016 tentang Standar Isi Kurikulum 2013 untuk Sekolah Dasar dan menengah. Bagian buku yang mengembangkan nilai-nilai karakter yaitu pada bagian materi pembelajaran dan aktivitas pembelajaran berupa materi, gambar, petunjuk kerja, pertanyaan, dan aktivitas kelompok.

Nilai-nilai karakter spiritual (religius)yang termuat dalam buku pegangan siswa IPA kelas VII semester 2 kurikulum 2013 sudah mengembangkan indikator pada karakter religius yaitu A1 (bersyukur), yang ditemukan sebanyak 2 kali pada bab sistem organisasi kehidupan makhluk hidup yaitu pada bagian refleksi halaman 12 dan 23. Indikator pada 
karakter religius A1 (bersyukur) juga ditemukan 1 kali pada bab pemanasan global bagian pendahuluan halaman 69 dan 1 kali pada bab tata surya bagian pendahuluan halaman 147. Sementara untuk 3 bab yang lain yaitu bab interaksi makhluk hidup dengan lingkungan, pencemaran lingkungan, dan lapisan bumi belum ditemukan secara tersurat di dalam bacaan namun tetap dapat dimunculkan dalam kegiatan pembelajaran seperti berdo'a dan beribadah sesuai agama dan keyakinan masing-masing. Karakter religius yang dikembangkan pada diri peserta didik diharapkan mampu menjadikan kehidupannya menjadi baik dan tidak menyimpang dari nilai-nilai agama yang berlaku. Hal tersebut sejalan dengan pendapat Azzet dalam (Ridwan dan Mudiono, 2017) yang menyatakan bahwa "apabila seseorang mempunyai karakteryang baik terkait dengan Tuhan Yang Mahakuasa, seluruh kehidupannya akan menjadi baik".

Muatan nilai-nilai karakter sosial (jujur, disiplin, santun, percaya diri, peduli, tanggung jawab, kreatif, rasa ingin tahu, menghargai kerja individu/kerja kelompok/pendapat orang lain, komunikatif, teliti, mandiri, dan kerjasama yang ditampilkan dalam Tabel 1 banyak ditemukan dalam kegiatan praktikum. Kegiatan praktikum merupakan ciri dari Kurikulum 2013 yang menggunakan pendekatan saintifik atau pendekatan ilmiah. Hal ini juga dibuktikan dengan temuan muatan nilai karakterdari frekuensi terbanyak ke frekuensi terkecil yaitu nilai karakterrasa ingin tahu, teliti, tanggung jawab, mandiri, menghargai kerja individu/kerja kelompok/pendapat orang lain, komunikatif, santun, jujur, percaya diri, kreatif, kerjasama, peduli, disiplin, dan gemar membaca yang ditemukan berturut-turut sebanyak 44 kali, 32, 30, 29, 27, 23, 21 18, 17, 16, 15, 10, 6, dan 6 kali.

Muatan nilai-nilai karakter tersebut di atas dapat dikembangkan dengan materi melalui pendekatan ilmiah (saintifik) yaitu kegiatan mengamati, menanya, mencoba penyelidikan, mencoba dan menguji prediksi, menalar/mengolah informasi dari hasil pengamatan dan mengkomunikasikan hasil pengamatan yang ditemukan pada seluruh bab dalam buku IPA SMP kelas VII semester 2 kurikulum 2013. Hal ini sejalan dengan tujuan utama mata pelajaran IPA yaitu pembentukan sikap ilmiah serta pemahaman tentang lingkungan dan alam sekitar beserta kekayaan yang dimilikinya (Kemdikbud 2013b).Pudlao, 2012 menjelaskan bahwa dalam mempelajari IPA, sikap ilmiah merupakan hal sangat penting dan harus ada pada diri seseorang. Diantara sikap ilmiah tersebut antara lainmemiliki rasa ingin tahu, berpikir kritis, open minded, jujur, memiliki keyakinan,objektif, berani mengambil risiko, bertanggung jawab,dan rendah hati. Berdasarkan hal tersebut dapat disimpulkan bawa nilai-nilai karakter yang terdapat dalam sikap ilmiah tersebut di atas juga diajarkan dalam pembelajaran IPA disamping mengajarkanilmu pengetahuan.Selain itu, dalam buku pegangan siswa IPA kelas VII semester 2 juga ditemukan nilai karakter gemar membaca yang sejalan dengan adanya gerakan literasi sekolah yang dikembangkan berdasarkan Permendikbud No. 21 Tahun 2015.

Buku pegangan IPA atau buku teks siswa SMP kelas VII semester 2 kurikulum 2013sudah menunjukkankesesuaian dengan yang telah dipaparkan dalam Permendikbud No. 21 Tahun 2016 dapat dikembangkan lagi. Guru merupakan aspek yang sangat penting dalam pembelajaran, akan tetapi buku teks juga tidak kalah pentingnya dengan guru. Kepercayaan siswa yang besar terhadap buku teks menyebabkan pengaruh buku teks lebih kuat daripada kata-kata yang mereka dengar dari guru atau orang tua.Bagdadi (2012). Oleh karena itu, kegiatan yang terdapat dalam buku teks atau buku pegangan siswa sangat tepat jika digunakan sebagai sarana pengembangan nilai karakter peserta didik. 


\section{SIMPULAN}

Muatan nilai karakter yang terdapat dalam Buku Pegangan Siswa IPA SMP Kelas VII Semester 2 Berbasis Kurikulum 2013sudahsesuai dengan uraian nilai-nilai karakter yang tercantum dalam Permendikbud No. 21 tahun 2016 tentang Standar Isi Kurikulum2013 untuk sekolah dasar dan menengah. Nilai-nilai karakter tersebut antara lain religius, jujur, disiplin, santun, percaya diri, peduli, dan tanggung jawab. Selain ke tujuh nilai karakter yang tercantum dalam Permendikbud No. 21 tahun 2016 tersebut di dalam buku pegangan siswa juga ditemukan 8 nilai karakter lain yaitu kreatif, rasa ingin tahu, menghargai kerja individu/kerja kelompok/pendapat orang lain, komunikatif, teliti, mandiri, dan kerjasama.

\section{SARAN}

Bagi peneliti selanjutnya, diharapkandapat menganalisis muatan nilai-nilai karakter pada buku pegangan siswa atau pegangan guru pada bab atau tema-tema yang lain sehingga nilainilaikarakter yang hendak dikembangkan melalui bahan ajar dapat teridentifikasi dengan jelas dengan disertai rubrik penilain pada masing-masing muatan nilai karakter yang ditemukan.

\section{REFERENSI}

Bagdadi, M. 2012. "A Comparison of GenderRepresentation in English (EFL) and Arabic (AFL) Textbooks in Iran:A Critical Discourse Analysis". The

Humanities and Social Sciences Collection,Vol. 8, No. 3, pp. 1-13.

Bohlin, K. E. 2005. Teaching Character Education Through Literature, Awakening the Moral Imagination in Secondary Classrooms.London: Routledge Falmer.
Chabalengula, V.M., Mumba F., Lorsbach T. \& Moore C. 1993. Curriculum and Instructional Validity of the Scientific Literacy Themes Covered in Zambian High School Biology Curriculum. International Journal of Environmental \& Science Education 3 (4):207-220.

Daryanto \& Dwicahyono. 2014. Pengembangan Perangkat Pembelajaran (silabus, RPP, PHB, bahan ajar). Yogyakarta: Gava Media.

[Kemdikbud] Kementerian Pendidikan dan Kebudayaan. 2013b. Permendikbud No 68 Tahun 2013 tentang Kerangka Dasar dan Struktur Kurikulum Sekolah Menengah Pertamal Madrasah Tsanawiyah. Jakarta: Kemdikbud.

[Kemdikbud] Kementerian Pendidikan dan Kebudayaan. 2013. Permendikbud No 21 tahun 2015 tentang Gerakan Literasi. Jakarta: Kemendikbud.

[Kemdikbud] Kementerian Pendidikan dan Kebudayaan. 2013. Permendikbud No 8 tahun 2016 tentang buku yang digunakan oleh satuan pendidikan. Jakarta: Kemendikbud.

[Kemdikbud] Kementerian Pendidikan dan Kebudayaan. 2013. Permendikbud No 20 tahun 2016 tentang Standar Kompetensi Lulusan Pendidikan Dasar dan Menengah. Jakarta: Kemendikbud.

[Kemdikbud] Kementerian Pendidikan dan Kebudayaan. 2013. Permendikbud No 21 tahun 2016 tentang Standar Isi Pendidikan 
Dasar dan Menengah. Jakarta: Kemendikbud.

Krippendorf, K. 2013. Content Analysis: An Introduction to Its Methodology. ThousandOaks: SAGE

Lewis, S. V., Robinson, E. H., \& Hayes, G.(2013). Implementing an Authentic

Character Education Curriculum.Olney: Taylor \& Francis Ltd.

Lickona, T. 2008. Pendidikan Karakter: Panduan Lengkap Mendidik Siswa Menjadi Pintar dan Baik. Terjemahan Irfan M. Zakkie: 2013

Pudlao, J. (2012, September 20). 10Scientific Attitudes. Retrieved from
Prezi:https://prezi.com/nki7ppklgo zo/10- scientific-attitudes/

Ridwan \& Mudiono. 2017. Analisis Muatan Nilai-Nilai Karakter Pada Buku Siswa Kelas IV Sekolah Dasar Tema Indahnya Kebersamaan. Jurnal wahana sekolah dasar (Kajian Teori dan Praktik Pendidikan) Tahun 25, Nomor 1,Januari 2017.

Siwi, dkk. 2016. Analisis Muatan Pendidikan Karakter dalam Buku Teks Pelajaran IPA Kurikulum 2013 pada Materi Biologi Kelas VII SMP. Unnes Journal of Biology Education 5 (2) (2016) : 207-213

Widodo, dkk. 2016. Ilmu Pengetahuan Alam SMP/MTs Kelas VII semester 2. Jakarta: Pusat Kurikulum dan Perbukuan, Balitbang, Kemdikbud. 